\title{
Impact after three years of the Swedish energy audit program
}

Sandra Backlund and Patrik Thollander

Linköping University Post Print

Tweet

N.B.: When citing this work, cite the original article.

Original Publication:

Sandra Backlund and Patrik Thollander, Impact after three years of the Swedish energy audit program, 2015, Energy, (82), 54-60.

http://dx.doi.org/10.1016/j.energy.2014.12.068

Copyright: Elsevier

http://www.elsevier.com/

Postprint available at: Linköping University Electronic Press

http://urn.kb.se/resolve?urn=urn:nbn:se:liu:diva-112267 


\title{
Impact after three years of the Swedish energy audit program ${ }^{1}$
}

\author{
Sandra Backlund, Patrik Thollander
}

\begin{abstract}
The Swedish energy audit program is a publicly financed program, mainly targeting small and medium-sized firms to help them finance energy audits. By examining suggested and implemented energy efficiency measures from the energy audits conducted in 241 firms in the program, the aim of this paper is to examine the energy efficiency implementation gap and the cost efficiency of the program.

The audits show that the firms' average annual energy efficiency improvement potential is between 860 and $1270 \mathrm{MWh} /$ year which corresponds to a total energy efficiency improvement potential of between 6,980-11,130 MWh / firm. The implementation rate of the suggested energy efficiency improvement measures in the SEAP is 53\%. The program has resulted in investments in energy efficiency improvements between $€ 74,100-€ 113,000$ / firm.
\end{abstract}

\section{Introduction}

In 2006 the Energy Service Directive (ESD) (EC, 2006) was launched by the European Commission (EC) and along with that an energy savings target of 9\% in the European Union. Since then the even stricter 20-20-20 energy savings target was introduced in 2008 and policies to improve energy efficiency in order to save energy in all sectors of society have been analysed and implemented. Whether improved energy efficiency leads to energy savings, that is, reduced total energy demand, has been discussed (e.g. Herring 2006) but improving energy efficiency is often argued as a no-regret measure.

One sector that has been pointed out to have large untapped potential for improved energy efficiency is small and medium-sized enterprises (SMEs) in the European Union. The challenge is that SMEs in Europe use large quantities of energy but the individual firms are often not energy intensive and since energy costs are relatively small for each firm they do not prioritize energy efficiency investments. The untapped potential has been explained further in numerous articles discussing barriers to energy efficiency in SMEs (e.g. Schleich and Gruber, 2008; Trianni and Cagno, 2012; Thollander et al., 2007). The ESD and later the Energy Efficiency Directive (EED) (EC, 2012) have advocated energy audits as a way to overcome barriers to energy efficiency and facilitate implementation of energy efficiency measures in the SME sector.

As a consequence of the European energy savings targets the Swedish energy audit program (SEAP) was introduced in 2010. The SEAP is a subsidy program that finances $50 \%$ of an energy audit up to $€ 3,000$. All firms that use more than $500 \mathrm{MWh} /$ year or farms with more

\footnotetext{
${ }^{1}$ Accepted with revisions in Energy, submitted revisions 10/03/2014
} 
than 100 livestock units may apply for the support. The Swedish Energy Agency (SEA) which is responsible for the program states that the energy audit report is supposed to function as a decision support to optimize firms' energy use. The audit report shall include energy use, how energy is distributed inside the firm and suggestions for energy efficiency measures.

By examining the reported energy audit data from the SEAP the aim of this paper is to examine energy efficiency improvement potentials presented in the audits, and the cost efficiency of the Swedish energy audit program.

\section{Background}

The prevailing consensus is that there is untapped potential for improved energy efficiency. The untapped potential for energy efficiency and by extension energy savings is commonly referred to as "the energy efficiency gap" (Hirst and Brown, 1990; Jaffe and Stavins, 1994) or the "energy paradox" (Weber, 1997). However, the magnitude of this EE potential is debated. The barrier theory is the widespread explanation to the discrepancy to why the potential for improving energy efficiency remains so large. The barrier theory is a theory that combines technical knowledge, economic theory, psychology and organizational theory to explain why energy efficiency measures are not being implemented (Sorrell et al. 2004). In 1997 Weber pointed out that barrier models assume that there is an ideal level of energy efficiency. Weber then categorized barriers to energy savings in four categories (institutional barriers, market barriers, organizational barriers and behavioural barriers) by asking the questions "what is the obstacle", "to whom is it an obstacle" and "what is it impeding". Sorrell et al. (2004) define a barrier as "a mechanism that inhibits a decision or behaviour that appears to be both energy efficient and economically efficient". Sorrell et al. (2004) define barriers in six broad categories: risk, imperfect information, hidden costs, access to capital, split incentives and bounded rationality. Policies focus on overcoming these barriers.

Numerous studies of barriers to energy efficiency in SME sectors have been done. Schleich et al. (2008) investigated barriers in commerce and the commercial sector and found that conflict between investor user and lack of information about energy consumption patterns were the main inhibitors. In an investigation of barriers to industrial SMEs in Sweden by Thollander et al. (2007) other priorities and access to capital were ranked highest. In 2012 Trianni and Cagno cautioned against bundling up conclusions about barriers to energy efficiency in different sizes and sectors, since there are vast differences in behaviour between different sectors. Despite that they concluded that across sectors two problems were recurring, access to capital and lack of information.

The perception of the potential for improving energy efficiency and the academic discourse on market barriers depend greatly on methodology and theoretical background. Jaffe and Stavins (1994) describe three different types of potential. The hypothetical energy efficiency potential is the energy efficiency level that would be reached if all of the most energyefficient technologies were implemented, regardless of risk, costs or maturity level and the energy system optimized. The technological energy efficiency potential is the potential where the benefit of a measure exceeds its investment cost. These potential studies are often done with bottom up calculations. The economic energy efficiency potential is the most limited 
potential because it also accounts for hidden costs, risks and opportunity costs. Economic potentials are often based on top-down calculations (Jaffe and Stavins, 1994). The difference in estimation hence lies in the view of costs and benefits. The costs, for the individual firm, of implementing an energy efficiency measures are the investment costs for the technology, capital costs and all the overhead costs or hidden costs that the implementation requires such as evaluation, making the decision, etc. The main benefit of an investment in energy efficiency for a profit-maximizing firm is reduced use of energy and reduced energy costs. To individual SMEs energy costs do not always have a large impact on financial result and therefore investing in energy efficiency measures is not always a priority. However it can be argued that energy use has social costs since not all negative externalities are included in the market price. When the benefits exceed the costs, implementation is efficient.

\subsection{Energy audit programs}

An energy audit is a type of indirect energy service (SEA, 2011). The service in itself does not improve energy efficiency but is considered an important step towards investing and implementing energy efficiency measures. Energy audits have been put forth both in political directives (EC, 2006; EC, 2012) and scientific literature (Schleich, 2004, Backlund et al., 2012) as a means to overcome barriers to energy efficiency and increase the deployment of energy efficient technologies. For an international overview see Price and Lu (2011) who provides information about energy audit programs in fifteen counties and stress the importance to consider country specific conditions when designing a national energy audit program. Bunse et al. (2011) state that energy audits and monitoring energy use is the first step towards increasing energy efficiency within a firm. Vine (2005) mentions energy audits as a way to increase diffusion of energy services, a market that has been highlighted as a tool to to facilitate implementation of energy efficiency measures (EC 2006). Abelaziz et al. (2011) describe it as a key ingredient for decision making in energy management.

The barrier theory, which is often used to explain why implicit discount rates are higher for energy efficiency measures than other kinds of investment, refers to lack of information as one of the most important barriers. The SEA argues that the energy audits from the SEAP are supposed to function as decision-making support for firms to implement and invest in energy efficiency measures.

This study draws on the experiences from previous studies of energy audit programs. Harris et al. (2000) evaluates an Australian energy audit program and found that implementation rates of energy efficiency measures were estimated as high as 80\%. Anderson and Newell (2004) evaluated the effects of energy audits offered by the US Department of Energy's Industrial Assessment Center. Adaptation rates of $53 \%$ of suggested measures were found, which represented $46 \%$ of total energy efficiency improvements. Anderson and Newell estimated that a firm's threshold payback time for energy efficiency investments is about one to two years. They also concluded that despite having received information about energy efficiency opportunities; implicit discount rates remained high relative to market interest rates. Tonn and Martin (2000) investigated decision making in the same program and found that the program 
had a significantly positive effect on energy efficiency decision-making in the participating firms.

In Germany Gruber et al. (2011) described the German energy audit program as successful with implementation rates of $77 \%$ of suggested energy efficiency measures. Thollander et al. (2007) evaluated Project Highland, a regional energy audit program in Sweden, where adaptation rates were estimated to be around 40\%. Thollander et al. (2007) found that the largest energy efficiency improvement potential in Project Highland was in the support processes, especially in space heating, and few of the suggested measures in the energy audits were targeting production processes. In a later analysis of the previously mentioned German energy audit program, Fleiter et al. (2012) came to the same conclusion that the largest implementation of energy efficiency measures was in the support processes. Furthermore Fleiter et al. (2012) also concluded that high investment costs impeded adoption of energy efficiency measures and that lack of capital slows down energy efficiency measure adoption. This is a result that corresponds with previous conclusions from studies on barriers to energy efficiency (e.g. DeCanio, 1998). Fleiter et al. (2012) also found that company size did not affect implementation rates. This contradicts the results from a study by Uhlaner et al. (2011) who recognized that characteristics of firms such as firm size, tangibility of the sector, perceived financial benefits, innovation orientation and ownership structure affect environmental management practices in Dutch SMEs.

\subsection{The SEAP}

The SEAP is mainly targeting SMEs since its extent limits the character of the energy audit. However, large firms with more than 250 employees and a turnover of more than $€ 50 \mathrm{M}$ are welcome to apply for the support if they can ensure that the SEAP will have a decisive impact on the conduct of the energy audit, and that the firm has not taken part in the Program for Improving Energy Efficiency in Energy-Intensive Industry, a policy directed towards electricity-intensive companies, see Stenqvist and Nilsson (2012). The energy audit can be conducted by internal staff but the SEA recommends consulting external help. The energy audit shall audit the firm's total energy use to get an overview of the energy flows. Firms with several plants at different locations can choose to target one plant but the individual firm can only apply for the support once.

After the audit is performed, an interim report from the audit must be turned in to the SEA in order for firms to receive the financial support. This is an interim report that shall contain the results from the energy audit, energy flows and an energy plan. After payment from the SEA a final report, including implemented and planned energy efficiency measures, shall be turned in. There are no requirements on what energy efficiency measures shall be implemented.

In 2010 an ex-ante evaluation of the SEAP was published by Dotzauer and Thollander (2010) but their evaluation assumed that the program would target manufacturing industries. Their pre-estimations were that the program would result in energy savings of 700-1400 GWh annually. 
In 2012 a process evaluation of the SEAP revealed points of improvement for the program. Among other things the cost efficiency and the quality control was criticised. The evaluation argued that in general the participating firms have little experience of energy audits and little time to spend on surveying the market for auditors. The cost of an energy audit should vary between different industries and premises, depending on facility and sector. To avoid the $€ 3000$ to set the standard fee for auditing all premises, the evaluation proposed a progressive disbursement support, based on for example aid in relation to annual energy cost. The evaluation also criticized the varying quality of the audit reports, ranging form 'excellent' to lacking relevant information. Therefore the evaluation suggested a training course for all auditors in the SEAP of the inclusion of a standardized energy audit tool providing guidance with monitoring, compilation of data and analysis. (Karlsson et al. 2012)

\section{Methodology and delimitations}

The SEAP was introduced in 2010 and the program will continue until 2014. This study includes firms that have received the support sometime between 2010 and 2012. A total of 554 participated in the SEAP during that timeframe. The analysis is based on all the interim reports that have been submitted to the SEA at the time of the analysis, a total of 241 reports.

All 241 reports have been thoroughly quality-controlled by the research group at Linköping University in collaboration with the SEA, and also compared to the original energy audits to ensure the quality of the data.

In the reports all suggested measures from the energy audits are reported as well as all measures that the firms claim to have implemented between 2010 and 2013 or will implement during 2014. The energy audits for these 241 firms resulted in 2217 suggested energy efficiency measures, these are the measures with quantified estimations of energy efficiency improvementssc. The suggested measures have been divided into 13 categories. The categories are Space heating, Space cooling, Ventilation, Tap water, Lighting, Compressed air, Internal transport, Pumping, Energy use in administration, Steam, Production process, Energy supply, Monitoring and Other. Energy balances and energy use have not been reported for most of the firms. Table 1 lists the categories and describes common measures for each category. To calculate total energy saving potentials the suggested energy efficiency measures were categorized in management measures and new investments. Management measures are measures that are described as adjustments of existing technology or behavioral changes these measures have been given an estimated lifetime of five years. Investments in new technology have been given an estimated lifetime of 12 years. These lifetimes are estimated inspired by Stenqvist and Nilsson (2012) who used the same estimations when evaluating the Program for Improving Energy Efficiency in Energy-Intensive Industry. 
Table 1: Energy efficiency measure categories

\begin{tabular}{|c|c|}
\hline Category & Type of measures \\
\hline Space heating & $\begin{array}{l}\text { Insulation of building envelope, temperature reduction, } \\
\text { replacement of windows, } \\
\text { Reduction of infiltration (sealing the building } \\
\text { envelope), utilization of waste heat from processes, } \\
\text { monitoring the heating system, } \\
\text { conversion of heating system, fans, etc. }\end{array}$ \\
\hline Space cooling & $\begin{array}{l}\text { Adjustment of the cooling system, } \\
\text { insulation of the building envelope, } \\
\text { temperature reduction of surfaces, } \\
\text { conversion of cooling system, etc. }\end{array}$ \\
\hline Ventilation & $\begin{array}{l}\text { Time control of ventilation, demand control of } \\
\text { ventilation new units, installation of heat/cold/moisture } \\
\text { recovery }\end{array}$ \\
\hline Tap water & $\begin{array}{l}\text { Installation of low-flow faucets and shower heads, } \\
\text { converting / replacement of water heater }\end{array}$ \\
\hline Lighting & $\begin{array}{l}\text { Installing more efficient lighting fixtures, } \\
\text { presence control / sectioning off the lights, etc. }\end{array}$ \\
\hline Compressed air & $\begin{array}{l}\text { Conversion of compressed air-driven processes to } \\
\text { electric drive, sealing of air system, } \\
\text { recycling of compressor heat, monitoring (variable } \\
\text { speed compressor., etc.), adjusting pressure, etc. }\end{array}$ \\
\hline Internal transport & $\begin{array}{l}\text { Streamlining of internal shipments, } \\
\text { conversion of energy carriers, eco-driving, etc. }\end{array}$ \\
\hline Pumping & $\begin{array}{l}\text { Time control of pumps, demand control of pumps } \\
\text { (sectioning, frequency, etc.), new pumps, etc. }\end{array}$ \\
\hline Administration & $\begin{array}{l}\text { Procedures for shutting down the office equipment, } \\
\text { energy efficient installations of printer, computers, } \\
\text { etc. }\end{array}$ \\
\hline Steam & $\begin{array}{l}\text { Reducing pressure, conversion of steam use, } \\
\text { installation of low-pressure turbine insulation, etc. }\end{array}$ \\
\hline Production processes & $\begin{array}{l}\text { Power control, reduction of idling losses, } \\
\text { streamlining of processes, conversion to other energy } \\
\text { carriers, changing to energy efficient motors }\end{array}$ \\
\hline Energy supply & $\begin{array}{l}\text { Power control, reducing peak load, } \\
\text { reducing losses in boiler and distribution, installation } \\
\text { of electrical generation, such as solar panels or wind, } \\
\text { etc. }\end{array}$ \\
\hline Monitoring & Monitoring of energy use, flows, temperatures, etc. \\
\hline Other & $\begin{array}{l}\text { Energy efficiency measures that does not fit other } \\
\text { categories }\end{array}$ \\
\hline
\end{tabular}

The categorizations of technologies are used to visualize average investment costs for different technological categories in a cost conservation curve. Cost conservation supply curves have been used since the 1970s to assess and break down costs for improving energy efficiency. One example of cost conservation supply curves for improving energy efficiency in industry is Worrell et al. (2000) who performed an analysis of energy efficiency measures 
in the US cement industry. McKayne and Hasanbeigi (2011) constructed energy efficiency supply curves models to estimate cost efficient electricity efficiency potentials for motor systems. Since the data from the SEAP only includes investment costs and no estimations of technical lifetime, these curves are simplified versions.

To perform the comparison between sectors the firms were divided into two groups. The Swedish categorization SNI2007 (identical to the European NACE Rev. 2) was used for this division. The categories are Manufacturing firms and Non- manufacturing firms. The nonmanufacturing firms consist of firms in the Commercial and service sector, Forest and agriculture sector and Other firms. Number of firms and SNI2007 numbers are reported in Table 2.

Table 2: Categorization of firms in the SEAP

\begin{tabular}{|l|l|l|l|}
\hline Sector & SNI2007 & Number of firms & $\begin{array}{l}\text { Number of suggested } \\
\text { measures }\end{array}$ \\
\hline Manufacturing industry & $10-33$ & 181 & 1676 \\
\hline $\begin{array}{l}\text { Commercial and service } \\
\text { sector }\end{array}$ & $45-96$ & 46 & 483 \\
\hline $\begin{array}{l}\text { Forest and agricultural } \\
\text { sector }\end{array}$ & $01-02$ & 11 & 58 \\
\hline Other & $38-42$ & 3 & 13 \\
\hline
\end{tabular}

\section{Results}

\subsection{Costs within the SEAP}

The average payment from the SEA to firms participating in the SEA was $€ 2,700$. According to the SEA the average cost for the energy audit, including consultant fees and the firm's internal work was $€ 7,500$. This figure is probably an under- estimation since $17 \%$ of the firms have not reported any internal costs.

In addition to this, the SEA has had other costs related to the SEAP: Approximately $€ 158,200$ for evaluation of the program and approx.. $€ 817,500$ for providing regional energy offices resources to hand market the SEAP locally. Between 2010 and 2014 the SEA spent approximately 5950 hours administrating the SEAP. Assuming that they add 1500 hours 2014 and adding the cost for internal evaluation (approx.. 160 hours) the costs for managing the program has been approx.. $€ 457,500$. For 2010-2012 the SEA has also reported costs for IT: $€ 58,100$, communication: $€ 19,500$ and other costs $€ 9,300$. All costs are reported in table 3 . 
Table 3: SEAs costs for managing the SEAP

\begin{tabular}{|l|l|}
\hline Cost & $€$ \\
\hline IT (2010-2012) & 58,200 \\
\hline Communication (2010-2012) & 19,570 \\
\hline Other costs (2010-2012) & 9,3060 \\
\hline Program evaluation & 158,200 \\
\hline $\begin{array}{l}\text { Support to regional public energy offices to supply } \\
\text { information about the SEAP }\end{array}$ & 817,500 \\
\hline Internal time SEA & 457,500 \\
\hline Total & $1,520,170$ \\
\hline
\end{tabular}

This means that SEAs estimate the average cost for managing each application in the SEAP ${ }^{2}$ is $€ 1,660$. Adding the average audit payment, the state expenses for the average audit is $€$ 4,360 . The total average cost for an energy audit in the SEAP is $€ 9,160$.

\subsection{Energy efficiency improvement}

The following results can be seen as a gross impact evaluation. A gross impact evaluation takes in to account all changes in energy use that results from a program. Gross impact evaluations do not regard any indirect effects such as free rider or multiplier effects. (Schiller 2007) The free rider effect is particularly difficult to estimate since it there are two free rider effects to measure in an energy audit program. First there is the question of whether the firms would have conducted an energy audit without the SEAP. This is how Fleiter et al. (2012) estimated the free rider effect of the German energy audit program who found a free rider effect of $9.1 \%$. However even if questions of the validity (it is a leading question) are not posed it does not cover the free rider effect of energy efficiency improvements in the firms since some of these measures could have been implemented even without an energy audit.

The energy audits for the 241 firms who sent in final reports resulted in 2043 suggested energy efficiency measures ${ }^{3}$ that added up to an energy efficiency improvement potential of about 255,00 MWh/year.

The firms state that they have implemented or plan to implement $48 \%$ of the number of suggested measures which corresponds to about 91,700 MWh/year. If a life time of twelve years is assumed for investments in new technology and five years for changes energy management measures, the average potential for energy efficiency improvement per firm in the SEAP is between $6,980 \mathrm{MWh}$ and $11,130 \mathrm{MWh}^{4}$. This means that the total expected gross energy efficiency impact potential of the program measures implemented between 2010 and 2012, that is in all 544 firms, lie between 2,797and 6,054 $\mathrm{GWh}^{5}$ in potential energy efficiency improvements. Figures for these measures as well as implementation rates for these measures are illustrated in Figure 1.

\footnotetext{
2 That is all firms in the program, circa 980

${ }^{3}$ These are all measures that included quantified estimates of energy efficiency improvements.

${ }^{4} 95 \%$ confidence interval

$595 \%$ confidence interval
} 


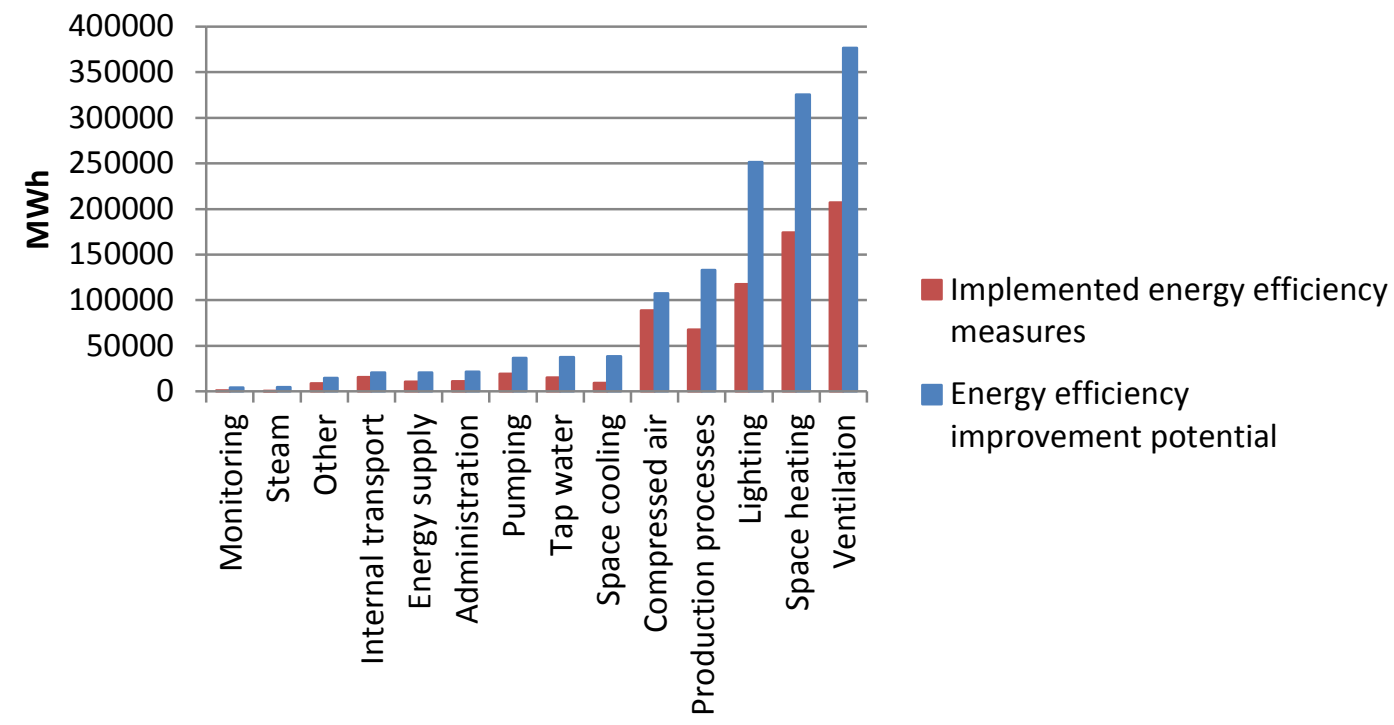

Figure 1: Suggested and implemented energy efficiency measures

\subsection{Suggested energy efficiency measures}

As can be seen in figure 1, Space heating and Ventilation are the two categories with the highest annual energy efficiency improvement potential and together they account for around $50 \%$ of the total suggested energy efficiency improvement measures. In table 4 annual energy efficiency improvements potential is presented as well as the total energy efficiency improvement potential. Energy efficiency per year is the estimated annual energy efficiency improvement potential. Energy efficiency improvement potential is the total estimated energy efficiency improvement potential calculated form estimated technical lifetimes.

Average energy efficiency improvement per firm is between 460 and $660 \mathrm{MWh} /$ year which corresponds to a total energy efficiency improvement of between $6980-11130 \mathrm{MWh}$. 
Table 4: Suggested and implemented energy efficiency measures and energy efficiency improvement (EEI) potentials from SEAP.

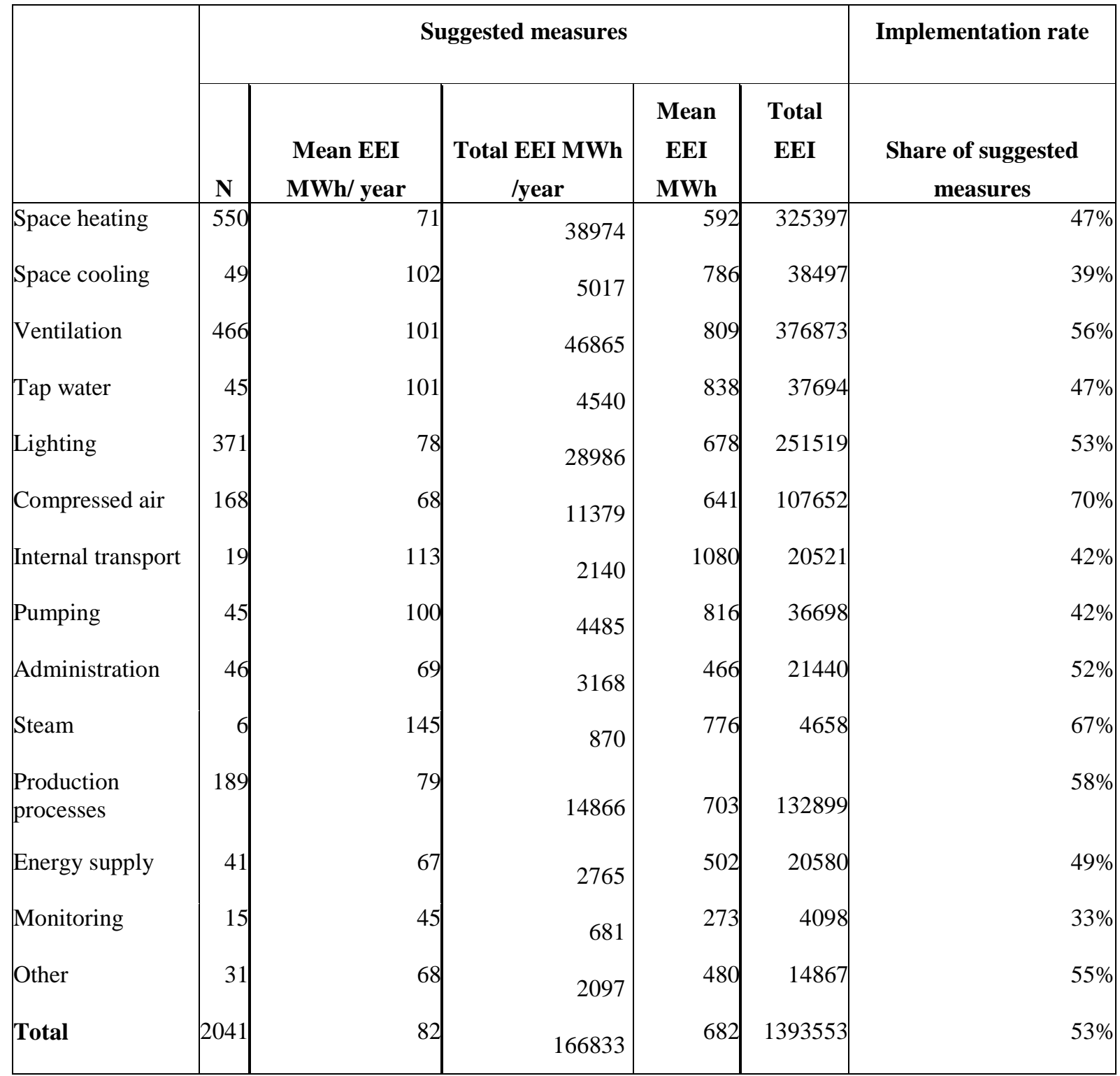

In Table 5 a comparison between energy efficiency improvement potential and implementation rates between firms in the manufacturing and the non-manufacturing sector is made. It can be seen that implementation rate is higher in manufacturing firms than in firms in non-manufacturing sectors. The difference between suggested measures and implemented measures can be seen as an implementation gap. 
Table 5: Average energy efficiency improvement potential comparison between Manufacturing industry and Non-manufacturing firms.

\begin{tabular}{|l|l|l|l|}
\hline \multirow{2}{*}{ Sector } & \multicolumn{2}{|l|}{ Suggested measures } & Implementation rate \\
\cline { 2 - 4 } & MWh/year & Total MWh & Total MWh \\
\hline Manufacturing industry & 1160 & 9110 & $59 \%$ \\
\hline Non- manufacturing sector & 750 & 8950 & $38 \%$ \\
\hline
\end{tabular}

\subsection{Investment costs}

In Figure 2 investment costs for the suggested and implemented measures in Figure 1 are illustrated. Investments costs are reported for 1848 of the measures. To implement all suggested energy efficiency measures around $€ 20,300,000$ is required in investments and the firms have reported to have invested $45 \%$ of that sum. This does not account for overhead costs, capital costs, transaction costs or other hidden costs, nor the cost for the conduction of the energy audit. The largest share of investments has been reported for Space heating and Ventilation.

In all energy efficiency measure categories the lowest reported investment cost is zero. This means that there are energy efficiency measures that do not require investments in new technologies. Of all suggested energy efficiency measures $11 \%$ do not require any investment cost and $28 \%$ of the measures require up to $€ 1,000$. Suggested measures that do not require investments in new equipment are typically energy management measures such as adjustments of existing technologies and behavioural changes within the firm. Suggested energy efficiency measures with such low investment costs answered for $9 \%$ of the energy efficiency improvement potential and the implementation rate for these measures is $66 \%$. More detailed information can be found in Table 6.

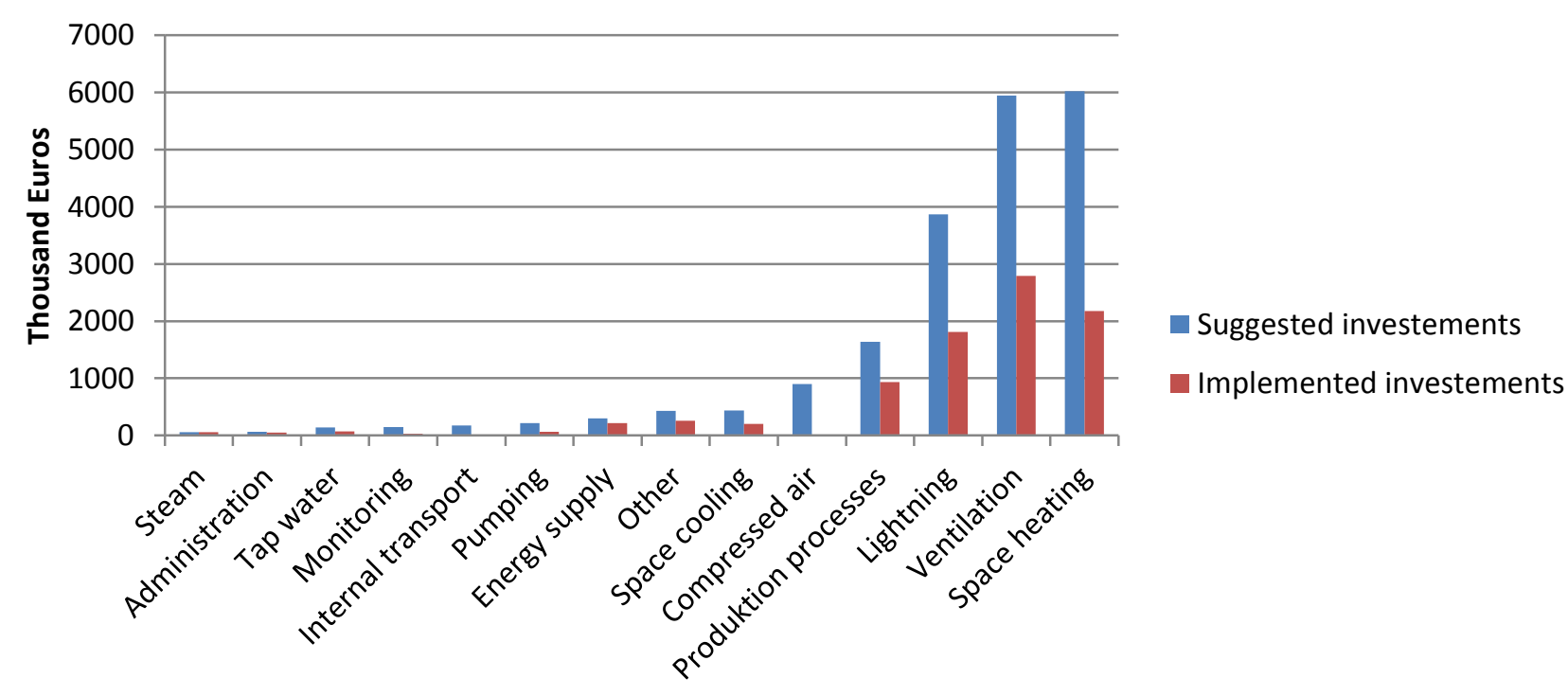

Fig 2: Investment costs for suggested and implemented energy efficiency measures in the SEAP 
Table 6: Investment costs for suggested and implemented measures from SEAP

\begin{tabular}{|c|c|c|c|c|}
\hline \multirow[b]{3}{*}{ Measure } & \multicolumn{2}{|c|}{ Suggested measures } & \multicolumn{2}{|c|}{ Implemented measures } \\
\hline & & Investment costs $€$ & Investment co & sts $€$ \\
\hline & $\mathrm{N}$ & Mean & Min & Mean \\
\hline Space heating & 484 & 12398 & 0 & 3752 \\
\hline Space cooling & 42 & 10191 & 0 & 3642 \\
\hline Ventilation & 427 & 13921 & 0 & 5921 \\
\hline Tap water & 39 & 3605 & 0 & 1513 \\
\hline Lightning & 363 & 10681 & & 4581 \\
\hline Compressed air & 160 & 5990 & 0 & 3195 \\
\hline Internal transport & 18 & 5856 & & 2700 \\
\hline Pumping & 49 & 4431 & 0 & 1235 \\
\hline Administration & 29 & 2310 & O & 1144 \\
\hline Steam & 6 & 10083 & $\Omega$ & 8557 \\
\hline Production processes & 163 & 10045 & 0 & 4800 \\
\hline Energy supply & 29 & 10231 & $\Omega$ & 5330 \\
\hline Monitoring & 10 & 14500 & 0 & 1813 \\
\hline Other & 29 & 14890 & 0 & 7169 \\
\hline Total & 1848 & 10991 & 0 & 4339 \\
\hline
\end{tabular}

\subsection{Average investment costs of improved energy efficiency}

The Average Investment Cost for the suggested measures in the SEAP is between $€ 125$ and $€ 183^{6} / \mathrm{MWh}$. The cost for the implemented measures in firms in the SEAP lie between $€ 87 /$ MWh and $€ 142^{7} / \mathrm{MWh}$. Table 7 show average investment costs for suggested and implemented measures in manufacturing and non-manufacturing firms. However, independent variable t-tests do not show statistically significant differences between manufacturing firms and non-manufacturing firms.

\footnotetext{
6 95\% confidence interval

$795 \%$ confidence interval
} 
Table 7 average investment costs $€ / M W h$ for suggested and implemented measures in $95 \%$ confidence interval in the SEAP. All figures in the table are presented in $€$

\begin{tabular}{|l|l|l|l|l|}
\hline \multirow{2}{*}{ Sector } & \multicolumn{2}{|l|}{ Suggested EEI measures } & \multicolumn{2}{l|}{ Implemented EEI measures } \\
\cline { 2 - 5 } & AIC/ annual MWh & AIC/ total MWh & AIC/ annual MWh & AIC/ total MWh \\
\hline Manufacturing firms & $940-1490$ & $110-170$ & $730-1340$ & $40-70$ \\
\hline Non-manufacturing firms & $540-1310$ & $100-250$ & $340-1100$ & $20-80$ \\
\hline
\end{tabular}

Cost conservation supply curves is an analytical tool that captures both technical potential and economic perspectives of energy efficiency improvements (McKane and Hasanbeigi 2011).

Both the magnitude of energy efficiency potential and the cost for implementing the measures is illustrated. Figure 3 is inspired by conservation supply curves and illustrates AIC for total energy efficiency improvement, assuming 12 year lifetime for investments in new technology and 5 year life time for management measures. See equation:

$$
\frac{A I C}{M W h}=\frac{A I C}{\text { Estimated energy efficiency potential } * \text { technical lifetime }}
$$

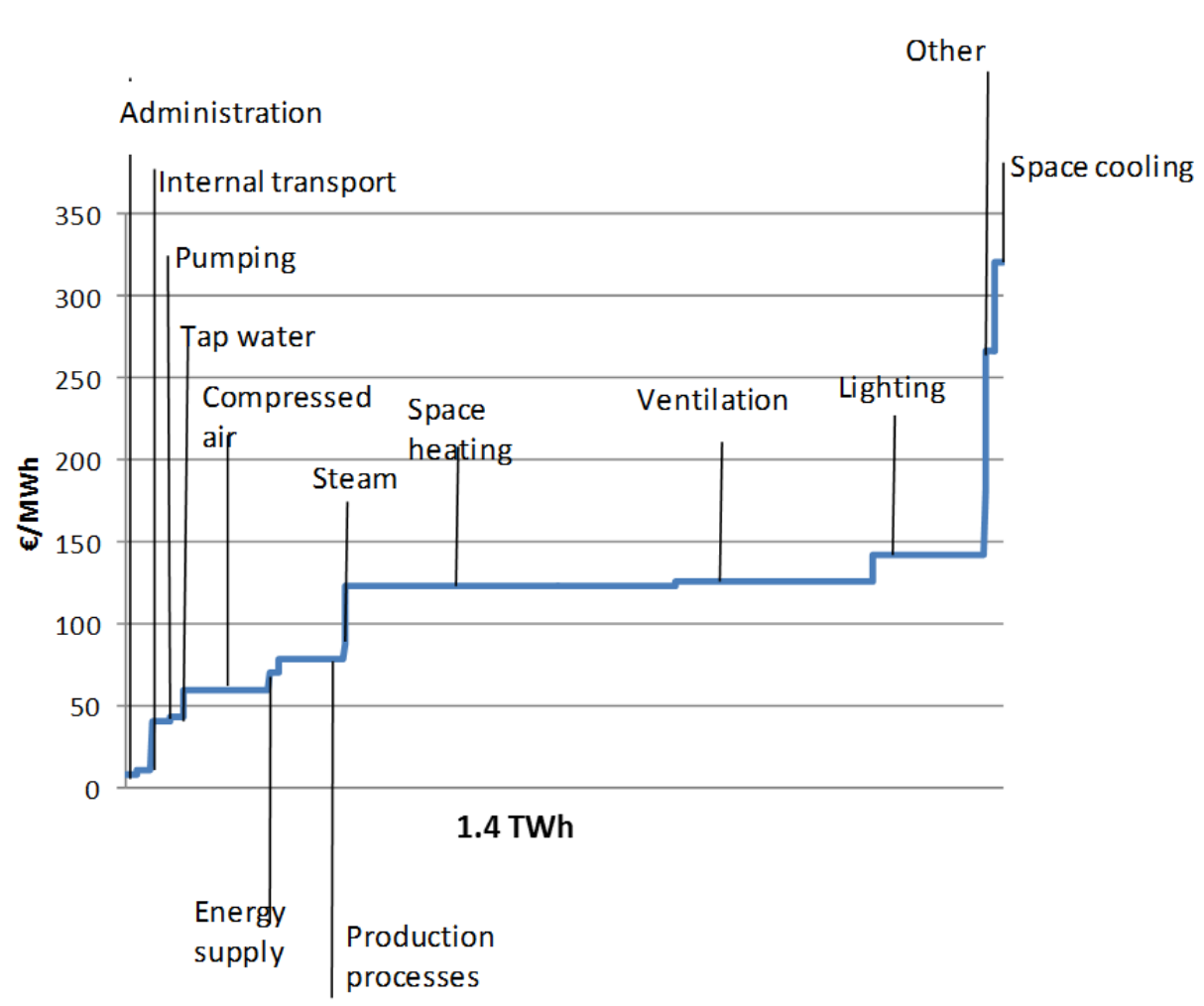

Figure 3: Average investment cost curve for suggested energy efficiency improvement measures in the SEAP 


\section{Concluding discussion}

This analysis of implementation of suggested energy efficiency measures cannot be seen as a full-scale impact evaluation of the program since the free rider coefficient has not been evaluated, i.e., how many of the audits would have been conducted anyway, and how many energy efficiency measures would have been implemented without the program. Moreover, as the program has yet not been terminated, the study naturally cannot present the impact of the whole program. It is not possible to conclude from this data how many energy audits would have been conducted even without the SEAP, nor would which measures have been found and implemented without the support. However, it can be seen as a preliminary gross impact evaluation of the first three years.

\subsection{Cost efficiency}

As an outcome of the SEAP the firms' average annual energy efficiency improvement potential is between 860 and 1,270 MWh/year which corresponds to a total energy efficiency improvement potential of between 6,980 -11,130 MWh / firm. The average energy audit in the SEAP has cost around $€ 9,160$ of which state expense is $€ 4,360$. Average implemented energy efficiency improvement per firms is between 460 and $660 \mathrm{MWh} /$ year. The program has resulted in investments in energy efficiency improvements between $€ 74,100$ - $€ 113,000$ / firm.

A relevant comparison that can be made to estimate cost efficiency of the SEAP is to compare it with the German energy audit program (Fleiter et al. 2012). The total cost for annual energy efficiency improvements in the SEAP is between $€ 125$ and $€ 265 / \mathrm{MWh}$. It does seem as if the energy efficiency improvements in the SEAP has been less expensive than the ones in the German audit program that had costs between $€ 225$ and $€ 625 / \mathrm{MWh}$.

The ex-ante evaluation of the SEAP predicted annual energy efficiency improvements between 700-1 $400 \mathrm{GWh}$, assuming a participation of 900 firms. (Dotzauer and Thollander 2010) This implies an average annual energy efficiency improvement between 780 and 1560 MWh per firm. The ex-ante evaluation expected the public cost to be $€ 0,25-0,5 / \mathrm{MWh}$. The results from this study show that the public cost lie between $€ 0,7-€ 1,3$ / MWh. The difference between the ex-ante evaluation and the outcome of the first three years might partly be explained by the points of critique presented in the process evaluation (Karlsson et al. 2012). It can also partly be explained by the fact that the ex-ante evaluation assumed that the program would only target manufacturing firms.

\subsection{Energy efficiency improvement potential and implementation gap}

The largest potential for energy efficiency improvements found in the audit reports is in support processes such as space heating and ventilation, both for manufacturing firms and non-manufacturing firms. This result is consistent with previous studies such as Thollander et al. (2007) and Fleiter et al. (2012). The fact that the greatest energy efficiency improvement potential in this data is found in support processes even for manufacturing firms does not necessarily reflect the 'true potential' but could be a reflection of the knowledge and expertise 
of the energy auditors who has conducted the audits. The effect of the energy auditors skills and expertise on energy audits is an interesting research topic that should be investigated in future studies.

The implementation rate of the suggested energy efficiency improvement measures is 53\%. This implementation rate is in line with results from previously mentioned studies of energy audit programs, a result very similar to the one by Anderson and Newell (2004) of 53\%. This indicates an implementation gap of $47 \%$. The reported suggested measures do not mention whether there is an overlap between measures, which means that some measures exclude the possibility of others. Still it can be assumed that the firms evaluate energy efficiency investments differently than the energy auditors. Finding out the reasons for the implementation gap would demand another data set and deeper analysis. Some results of factors affecting implementation rates are still worth commenting on.

Access to capital and difficulties financing investments in energy efficiency improvements has been put forth as one of the most important barriers to improving energy efficiency (Trianni and Cagno 2012, de Groot et al., 2001, Schleich and Gruber, 2008, Sardianou, 2008). A total of $28 \%$ of the suggested energy efficiency measures that accounted for $9 \%$ energy efficiency improvement potential in the SEAP did not require large capital investments, less than $€ 1000 /$ measure. The implementation rate between measures that demand zero or low capital investments is slightly higher than the measures that demand large capital investments, therefore investment costs seem to affect adoptation, as also found the evaluation of the American IAC (Anderson ad Newell (2004), . This result is consistent with results from barrier studies.

\section{Acknowledgments}

The work has been carried out under the auspices of the Energy System Program, funded by the Swedish Energy Agency. Thank you to Svetlana Paramonova, Joel Forsberg, Joel Österqvist, Danica Ilic and Kaihong Sun at Linköping University, for helping to qualitycontrol the data from the SEAP. 


\section{References}

Abdelaziz E.A., Saidur R., Mekhilef S., 2011, A review on energy saving strategies in industrial sector, Renewable and Sustainable Energy Reviews 15 : 150-68

Anderson, S., Newell, R.G., 2004, Informational programs for technology adaptation: the case of energy efficiency audits, Resource and Energy Economics 27-50

Backlund, S., Thollander, T., Palm, J., Ottosson, M., 2012, Extending the energy efficiency gap, Energy Policy, 51: 392-396

Bunse, K.., Vodickaa, M., Schönslebena P., Brülhartb, M., Ernstb, F. O., 2011, Integrating energy efficiency performance in production management - gap analysis between industrial needs and scientific literature, Journal of cleaner production, 19: 667-679

DeCanio, S. J., 1998, The efficiency paradox: bureaucratic and organizational barriers to profitable energy-saving investments, Energy Policy, 26: 441-454

Dotzauer, E., Thollander, P., 2010, An energy efficiency program for Swedish industrial small- and medium-sized enterprises, Journal of cleaner production 13: 1339-1346

EC (European Commission), 2006, Communication from the Commission. Action Plan for Energy Efficiency: Realizing the Potential. COM (2006) 545 Jaffe, A.B., Stavins, R.N., 1994. The energy efficiency gap: what does it mean? Energy Policy 22 (10): 60-71.

EC (European Commission), 2006, Directive 2006/32/EC

EC (European Commission), 2012, Directive 2012/27/EU

Fleiter, T., Schleich, J., Ravivanpong, P., 2012, Adoption of energy efficiency measures in SMEs - An empirical analysis based on energy audit data, Energy 51: 863-875

Gruber, E., Fleiter, T., Mai, M., Frahm, BJ., 2011, Efficiency of an energy audit program for SMEs in Germany - results of an evaluation study, ECEEE Summer study 2011

Karlsson, M., Thollander, P., Rohdin, P., 2012, Impact and process evaluation of the Swedish national energy audit program for small and medium-sized industries, ECEEE industrial Summer study 2012

McKane , A., Hasanbeigi, A., 2011, Motor systems energy efficiency supply curves :A methodology for assessing, Energy policy, 39: 6595-6607

the energyefficiencypotentialofindustrialmotorsystems

Harris, J., Anderson, J., Shafron, W., 2000, Investments in energy efficiency: a survey of Australian firms, Energy Policy 28, 867-876

Herring, H., 2006, Energy efficiency - a critical view, Energy, 31:10-20 
Hirst, E., Brown, M.A., 1990. Closing the efficiency gap: barriers to the efficient use of energy. Resources, Conservation and Recycling 3,267-281.

Jaffe, A.B., Stavins, R.N., 1994, The energy efficiency gap: what does it mean?, Energy Policy, 22, 60-71

Price, L., Lu, H, 2011, Industrial Energy Auditing and Assessments: A Survey of Programs Around the World, ECEEE Summer study 2011

Schleich J., 2004, Do energy audits help reduce barriers to energy efficiency? An empirical analysis for Germany. International Journal of Energy Technology and Policy 2:226-239.

Schleich J., Gruber E., 2008, Beyond case studies: Barriers to energy efficiency in commerce and the services sector. Energy Economics 30:449-464.

SEA, 2011, Analys av den svenska marknaden för energitjänster, ISSN 1403-1892

Sardinio, E., 2008, Barriers to industrial energy efficiency investments in Greece, Journal of Cleaner Production, 13: 1416-1423

Sorrell, S., O’Malley, E., Schleich, J., Scott, S., 2004, The economics of energy efficiency barriers to cost-effective investment, Cheltenham, UK: Edward Elgar.

Stenqvist, C., Nilsson, L.J., 2012. Energy efficiency in energy-intensive industries - an evaluation of the Swedish voluntary agreement PFE. Energy Efficiency, 5(2): 225-241. Tonn, B., Martin, M., Industrial energy efficiency decision making, Energy Policy, 28: 831- 843

Thollander,P., Danestig, M., Rohdin, P., 2007, Energy policies for increased industrial energy efficiency: evaluation of a local energy program for manufacturing SMEs, Energy Policy, 35: 5774-5783

Tonn, B., Martin, M., Industrial energy efficiency decision making, Energy policy, 28: 831843

Trianni, A., Cagno, E., 2012, Dealing with barriers to energy efficiency and SMEs: Some empirical evidences, Energy 37: 494-504

Vine, E., 2005, An international survey of the energy service company (ESCO) industry, Energy Policy 33: 691-704

Weber, L., 1997, Some reflections on barriers to the efficient use of energy. Energy Policy, 25(10): 833-835.

Worrell, E., Martin, N., Price, L., 2000, Potentials for energy efficiency improvement in the US cement industry, Energy 25:1189-1214 